\title{
KONSESI BRITISH DI TIANJIN SEBELUM 1925: SATU BENTUK IMPERIALISME DI CHINA
}

\author{
Suffian Mansor
}

\begin{abstract}
British Concession in Tianjin was part of the British informal Empire. The existence of this concession was because of the demand of the British businessmen for their own settlement. The British government asked the Chinese government to give them land in Tianjin to create their own settlement. This settlement which had its own authority and power could not be challenged by Chinese authority. This concession steadily grew and created a mini European styled city: However it was not only the appearance of the city as a European city miniature, the British who lived in the concession created a British cultural environment that included several English clubs, bars and racecourse. To the Chinese, the development of this concession created a negative feeling towards the foreign imperialist who did not respect Chinese sovereignty. Therefore this concession and other foreign concessions became the thorn in the Chinese people against the foreign imperialism.
\end{abstract}

\section{Pengenalan}

Apabila membicarakan tentang imperialisme di China, konsesi asing merupakan salah satu bentuk imperialisme yang dikenali sebagai informal empire di China. Konsesi asing di China adalah satu penempatan asing yang tidak tertakluk kepada pentadbiran dan penguasaan orang China. Oleh kerana bentuknya sedemikian maka konsesi ini dianggap sebagai salah satu elemen dalam imperialisme asing di China. Pembentukan konsesi asing ini bermula apabila Perjanjian Nanking ditandatangani pada tahun 1842. Antara bandarbandar pelabuhan perjanjian yang terdapat konsesi ini ialah di Shanghai, Pulau Shamen di Guangzhou, Hankou dan Tianjin. 
Kuasa asing seperti British, Perancis, Jepun, Itali, Jerman dan Rusia memiliki beberapa konsesi di China. British misalnya memiliki enam konsesi di China. Pihak China hanya dapat menuntut balik kekuasaan mereka ke atas konsesikonsesi ini pada tahun 1943 dan 1946. Artikel ini akan cuba merungkaikan elemen-elemen imperialisme dalam konsesi ini dan cuba melibatkan bagaimana elemen-elemen ini mengukuhkan sikap kolonalisme orang asing di China. Perbincangan hanya akan tertumpu kepada konsesi British di Tianjin dan kaitan konsesi-konsesi asing lain dengan Tianjin. Jangkamasanya adalah dari tarikh penubuhan konsesi ini dalam tahun 1861 sehingga 1925. Namun demikian, perbincangan juga akan serba sedikit meliputi sejarah awal Tianjin secara ringkas dan juga kesan-kesan perkembangan konsesi ini selepas 1925 secara rawaknya. Perbincangan ini akan dimulakan dengan sejarah awal Tianjin secara ringkas.

\section{Sejarah Awal Tianjin}

Tianjin merupakan sebuah bandaraya yang terletak di timur laut China yang berdekatan dengan Teluk Pohai. Bandaraya ini berhampiran dengan bandaraya Beijing. Sebelum kedatangan Orang Barat ke China, Tianjin telah berkembang dari sebuah perkampungan nelayan dan petani di Lembah Sungai Hai kepada sebuah pusat perdagangan yang penting di utara China. Perkembangan awal bandaraya ini boleh dikesan sejak tertubuhnya Dinasti Sui (581-618). Walaupun hayat dinasti ini agak singkat tetapi usaha-usaha pemimpin mereka seperti Maharaja Wen Ti (581-604) telah meletakkan batu asas dalam pembangunan Tianjin.

Maharaja Wen Ti telah menjalankan usaha pembinaan terusan besar (Grand Canal) yang merentasi Tianjin bagi menghubungi kawasan utara dengan kawasan tengah dan selatan China.' Pembinaan terusan ini membantu memacukan pembangunan Tianjin. Manakala pemilihan Beijing oleh Kublai Khan sebagai ibu negeri bagi Dinasti Yuan (1279-1368) seterusnya membantu Tianjin terus berkembang sebagai pusat pengumpulan makanan untuk Beijing. Semasa Dinasti Ming (1368-1644) pula satu unit pengawal ditubuhkan di Tianjin untuk menjaga dan memperkemaskan lagi kawalan laluan makanan di bandar tersebut. ${ }^{2}$ Pada tahun 1404 pula tembok-tembok batu yang tinggi telah dibina di Tianjin. ${ }^{3}$ Dengan itu juga Tianjin dikenali sebagai Ford of Heaven. ${ }^{4}$ Salah satu lagi kepentingan yang membawa kemajuan kepada Tianjin adalah ia juga dikenali sebagai pusat pengeluaran garam. Aktiviti pengeluaran garam boleh dikesan sejak sebelum abad masihi lagi. ${ }^{5}$

Oleh kerana aktiviti-aktiviti ini, Tianjin telah mempunyai ciri-ciri sebagai sebuah pelabuhan yang berdaya maju. Atas sebab itu juga Tianjin menjadi tarikan kepada pedagang asing untuk singgah berdagang di utara China. Namun demikian, kerajaan China di bawah Dinasti Ch'ing (16441911) tidak menggalakkan perdagangan atas sebab-sebab keselamatan dan akhirnya mengamalkan dasar tutup pintu. Dasar ini hanya menghadkan perdagangan kepada satu pelabuhan sahaja iaitu di Guangzhou (Canton). 
Dasar ini diumumkan oleh pihak Maharaja China pada tahun $1757 .{ }^{6}$ Dengan kata lain Tianjin juga ditutup kepada perdagang asing. Dengan terhadnya perdagangan ini menyebabkan orang Barat cuba merayu. Pelbagai utusan telah dihantar oleh orang Barat seperti utusan British di bawah Lord Macartney (1793) dan Lord Amherst (1819) telah menemui kegagalan. ${ }^{7}$

Keadaan ini menimbulkan ketegangan yang akhirnya mencetuskan peperangan di antara pihak Barat dengan China. Perang pertama meletus pada tahun 1839 yang dikenali sebagai Perang Candu telah membuka China kepada pedagang-pedagang asing terutamanya dengan kuasa Barat. Sejajar dengan itu juga beberapa pelabuhan China dibuka kepada pedagang asing. Namun demikian Tianjin masih ditutup kepada pedagang asing sehingga 1860. Pembukaan pelabuhan Tianjian berlaku rentetan daripada perang kedua (Perang Arrow) antara British dan Perancis dengan China pada tahun 1856. Namun demikian Tianjin masih lagi tidak dibuka kepada pedagang asing selepas perang tersebut. Pembukaan Tianjin hanya berlaku apabila Konvensyen Peking yang ditandatangani pada tahun $1860 .^{8}$

\section{Pembentukan Konsesi}

Dengan termeterainya Konvensyen Peking, pihak berkuasa China membenarkan kuasa asing membuka penempatan mereka sendiri di Tianjin. Tiga kuasa Barat pertama yang diberi hak penempatan ini ialah British, Perancis dan Amerika Syarikat. Dari tiga kuasa ini, hanya British dan Perancis menunjukkan minat untuk membuka penempatan asing atau konsesi di Tianjin. Manakala Amerika Syarikat tidak menunjukkan minat untuk memajukan penempatan asing mereka sehingga dicantumkan menjadi sebahagian daripada konsesi British pada Oktober 1902." Pihak British dan Perancis diberi kawasan selatan bandar Tianjin dan berdekatan dengan tebing Sungai Hai. (rujuk peta di bawah)

Konsesi-konsesi ini telah dibangunkan dengan menukar corak penggunaan tanah di kawasan penempatan mereka daripada sebuah kawasan kebun sayuran dan penempatan nelayan kepada beberapa lot-lot tanah untuk membina jalanraya, gudang-gudang, bangunan pentadbiran dan jeti. ${ }^{10}$ Bersama-sama dengan pembangunan ini, rumah-rumah kediaman, kedai dan bangunan-bangunan syarikat mula tumbuh secara pelahan-lahan. Orang yang bertanggungjawab dalam pembangunan penempatan British di Tianjin ialah Kolonel Charles George Gordon. " Beliau mengetuai penduduk British yang hanya berjumlah puluhan orang bagi membangunkan konsesi British ini.

Pada tahun 1862, sebuah majlis perbandaran ditubuhkan bagi mentadbir konsesi British ini. Pada peringkat awal ahli-ahli majlis ini terdiri daripada tiga orang ahli. Jumlah ini meningkat setahun demi setahun. Contohnya pada tahun 1867 bertambah kepada empat orang dan 1874 pula bertambah kepada lima orang. Angka ini terus bertambah kepada enam orang pada tahun 1882 dan sembilan pada tahun 1919. Keahlian dalam majlis ini dipilih oleh pengundi berdasarkan berapa banyak harta yang mereka miliki di konsesi ini. Oleh 
kerana itu kesemua ahli-ahli majlis ini adalah ahli peniagaan. Namun demikian dari segi komposisi kewarganegaraan pada peringkat awal, ahli-ahlinya terdiri daripada pelbagai bangsa. G. Detring yang berbangsa Jerman misalnya pernah menjadi pengerusi majlis ini pada tahun 1887-1889. Manakala A. D. Startseff berbangsa Rusia pula pernah menjadi bendahari kehormat majlis tersebut pada tahun 1887-1889. Sebelum abad ke-20, hanya seorang berbangsa China dilantik sebagai ahli iaitu Liao Too Sang pada tahun 1878 .

\section{Kedudukan Konsesi-konsesi Kuasa Barat Sekitar 1860an}

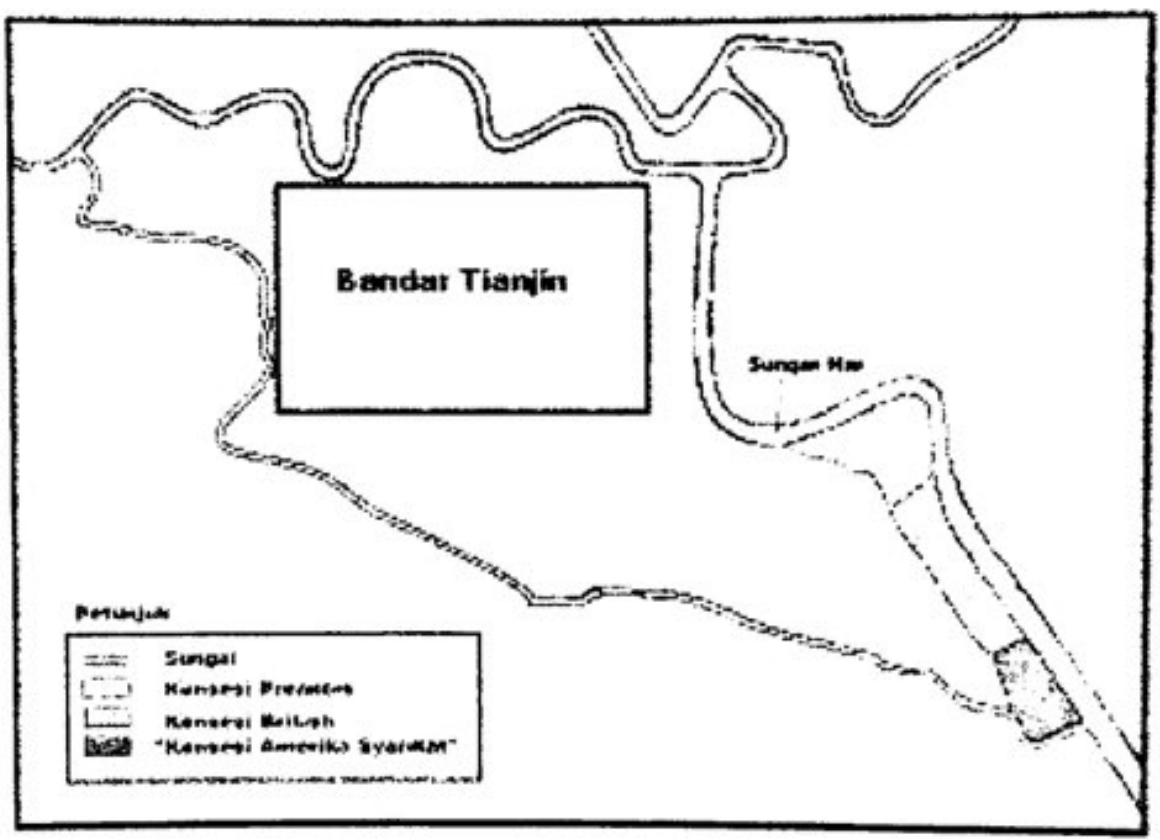

Sumber: Koleksi Peribadi (Dr. Suffian Mansor)

Pada peringkat awal Majlis Perbandaran British Tianjin (MPBT) ini mempunyai seorang persuruhjaya. Tugas beliau adalah meliputi soal berkaitan dengan kerjaraya dan polis. ${ }^{12}$ Peranan Persuruhjaya ini menunjukkan bahawa usaha awal MPBT hanya tertumpu kepada soal-soal kerjaraya dan keselamatan. Oleh kerana peranan persuruhjaya ini semakin hari semakin besar maka kerjaraya dan keselamatan dipisahkan pada tahun-tahun 1880-an. Oleh itu terdapat jawatan Persuruhjaya Kerjaraya dan Inspektor polis. Inspektor polis ini dibantu oleh dua orang sarjan polis dan 25 konstabel. ${ }^{13}$ Pada tahun 1893 jumlah ini bertambah iaitu terdapat tiga orang sarjan, manakala jumlah konstabel pula bertambah kepada 30 (1891), 33 (1892), 35 (1893) dan $40(1895) .^{14}$ 
Sementara itu, konsesi ini mencapai kemakmuran hasil daripada perdagangan yang datang dari wilayah-wilayah China utara. Manchuria misalnya mempunyai sumber bahan api yang banyak dan menyediakan kawasan pertanian yang luas. Manakala Shaanxi, Shenxi, Gansu dan Mongolia menyediakan bahan mentah seperti bulu binatang untuk dieksport. Oleh kerana itu, Tianjin menjadi salah sebuah pusat industri karpet utama dunia ketika itu. Kedudukan Tianjin yang berdekatan dengan Beijing, memyebabkan pelabuhan Tianjin menjadi pelabuhan perantaraan sebagai pintu masuk barang-barang import ke ibu negara China itu dan juga kawasan sekitarnya. Disebabkan peranan Tianjin ini maka ia dikenali sebagai 'the business heart of North China and Mongolia' dan 'the Shanghai of North China'. is

\section{Ketegangan Kaum antara China dan Barat}

Kehadiran penduduk asing dan kewujudan konsesi mereka ini menimbulkan rasa kurang senang penduduk China di Tianjin. Walau bagaimanapun sikap anti-orang Barat ini telah tertanam dalam pemikiran penduduk China sejak Perang Candu (1840-1842) lagi. Mereka menggelarkan orang Barat ini sebagai Fan Gui iaitu hantu laut yang tidak bertamadun. Apabila China dikalahkan oleh British dalam Perang Candu, orang Barat mula menuntut pelbagai keistimewaan seperti penempatan asing dan hak menyebar agama Kristian. $\mathrm{Hal}$ ini membawa kepada kemarahan dan kebimbangan penduduk China ke atas kegiatan mubaligh Kristian yang bergerak bebas di China. Mereka juga risau akan bahayanya gerakan Kristian ini yang boleh mengancam kepercayaan tradisi masyarakat China. Oleh itu berlakunya serangan daripada penduduk China ke atas mubaligh Kristian dan harta benda mereka. Sebagai contohnya ialah di Nanchang pada tahun 1862, rumah anak yatim orang Kristian telah dibakar dan beberapa rumah dan kedai milik penduduk China Kristian juga musnah dibakar oleh penduduk China. Di Yangchow juga station mubaligh Kristian juga telah diserang dan dimusnahkan pada tahun $1868 .{ }^{16}$

Sentimen kemarahan penduduk China juga menjalar ke Tianjin sehingga terdapat dua insiden besar yang mencabar konsesi asing di Tianjin pada 1900. Pertama ialah insiden Tianjin Massacre yang telah menyebabkan kematian ke atas penduduk asing. Insiden pertama ini berpunca daripada aktiviti mubaligh Kristian yang mencari anak-anak yatim untuk dipelihara. Badan Kristian yang dikenali sebagai Sisterhood of Mercy mencari kanak-kanak yang ditinggalkan atau anak yatim untuk dipelihara. Mereka menawarkan hadiah kepada sesiapa yang dapat membawa kanak-kanak ini kepada mereka. Keadaan ini menyebabkan tersebarnya khabar angin bahawa golongan mubaligh ini cuba menculik kanak-kanak untuk mendapat mata dan hati. Akhirnya khabar angin ini tersebar luas dan membawa kepada perasaan takut bercampur marah serta benci penduduk China terhadap orang asing. ${ }^{17}$

Selain itu, kemarahan mereka juga berpunca daripada tindakan pihak berkuasa Perancis menukarkan Imperial Palace kepada konsulat Perancis dan mengambil tapak tanah Kuil Buddha untuk dijadikan gereja Kristian. ${ }^{18}$ 
Akhirnya penduduk China menyerang harta benda penduduk Perancis termasuk gereja dan bangunan konsulat Perancis. Seramai 21 orang terbunuh dan kebanyakannya ialah orang Perancis termasuk konsulnya iaitu $\mathrm{M}$. Fontainer. ${ }^{19}$ Oleh kerana punca utama kemarahan penduduk China ini ialah ke atas penduduk Perancis, maka penduduk British dan harta mereka terselamat daripada serangan penduduk China. Hanya kesilapan mengenal identiti mangsa menyebabkan kematian tiga orang Rusia dalam insiden tersebut. Walaupun insiden ini tidak secara terus mengancam penempatan orang asing tetapi kehadiran penduduk asing yang tidak mengenal adat resam tempatan mengakibatkan ketegangan penduduk asing dengan penduduk tempatan.

Insiden kedua pula berpunca daripada peibagai faktor seperti kesan perang China-Jepun (1894-1895), kemarau dan banjir di Shantung, Henan dan Kiangsu dan aktiviti-aktiviti pengembang agama Kristian. ${ }^{20}$ Perang China Jepun membawa kepada kekalahan China yang terpaksa akur untuk melunaskan ganti rugi 340 juta tahil bagi ganti rugi perang kepada Jepun. Jumlah itu dianggap sebagai satu per tiga daripada hasil China. Bagi membayar ganti rugi ini, kerajaan China terpaksa membuat pinjaman luar. Selain mendapat pinjaman luar, kerajaan China juga menaikkan cukai-cukai ke atas penduduknya bagi menampung tuntutan ganti rugi daripada pihak asing. Nilai cukai ini dikatakan telah naik dua kali ganda sejak era pemerintahan Maharaja Tung Chih (1862-74). ${ }^{21}$

Pada masa yang sama penduduk tempatan di Shandong, Henan dan Kiangsu mendapat kesusahan kerana hasil pertanian mereka musnah dilanda banjir dan kemarau. Manakala kegiatan mubaligh Kristian pula memburukkan keadaan apabila membantu penjenayah-penjenayah China yang memeluk Kristian daripada dihukum oleh pihak berkuasa China. Malahan mereka turut campurtangan dalam kes-kes pertikaian penduduk tempatan yang melibatkan orang Kristian China, ${ }^{22}$ seperti dalam urusan harta kampung, perebutan tanah dan penggunaan kemudahan awam.

Terdapat kira-kira 700 kes pertelingkahan agama berlaku antara 1856 sehingga $1899 .{ }^{23}$ Perasaan anti Kristian ini diapikan lagi dengan khabar angin menerusi risalah dan poster yang tersebar secara bebas ${ }^{24}$ mengutuk ajaran agama tersebut. Antara perkara yang dinyatakan bahawa pengembang agama ini akan mencungkil mata kanak-kanak untuk tujuan membuat barangan logam yang berharga. Selain itu terdapat juga tuduhan mengatakan pemeluk agama Kristian dalam kalangan orang Cina menjalankan aktiviti tidak bermoral dengan anak perempuan mereka. ${ }^{25}$

Sebab-sebab di atas telah membawa kepada ketegangan di utara China. Pada masa yang sama satu kumpulan yang mengamalkan seni mempertahankan diri mula tampil memimpin rakyat China untuk mengembalikan keagungan dan memulihkan kehidupan rakyat. Persatuan mempertahan diri yang dikenali oleh orang Barat sebagai Boxer ini mula menjadikan orang asing sebagai sasaran kerana membawa kepada malapetaka terhadap China. Walau bagaimanapun aktiviti mereka yang pada asalnya berpusat di Shantung telah 
dapat dibendung oleh Gabenor Yuan Shih-kai. ${ }^{26}$ Walaupun usaha menghapuskan golongan Boxer ini berjaya namun, golongan Boxer ini telah mengerakkan aktiviti mereka ke utara termasuk Tianjin.

Kemuncak aktiviti mereka ini bermula pada tahun 1900 apabila mereka mula menyerang secara terbuka ke atas orang Cina Kristian dan pengembang agama Kristian. Sebelum itu, iaitu pada 31 Disember 1899, di Feichang, Semenanjung Shantung, pengembang agama Kristian pertama berketurunan Inggeris bernama Paderi S.M. Brooke telah dibunuh. Kematian beliau telah membawa kepada bantahan Menteri British, Sir Claude MacDonald yang menuntut pihak China memohon maaf. ${ }^{27}$ Walaupun pembunuhnya telah ditangkap dan dijatuhkan hukuman bunuh, ${ }^{28}$ namun demikian hukuman tersebut tidak menakutkan dan menghentikan aktiviti Boxer. Aktiviti mereka terus dijalankan di Beijing dan Tianjin yang telah menyaksikan kumpulan Boxer ini telah membunuh orang Kristian yang membawa kepada kekacauan dalam kedua-dua bandar tersebut. Pada 11 Jun 1900, Canselor Jepun Sugiyama juga turut terkorban. ${ }^{29}$

Pada 20 Jun 1900 Menteri Jerman iaitu Baron von Ketteler juga menjadi mangsa serangan dari kumpulan Boxer. ${ }^{30}$ Manakala di Peking, Maharani Dowager Tzu Hsi melihat kekacauan yang ditimbulkan oleh Boxer ini memberi harapan kepada beliau untuk menghalau kuasa asing dari China. Maharani Tzu Hsi ini yakin dengan kejayaan Boxer telah mengisytiharkan perang pada 21 Jun 1900 ke atas semua kuasa asing. ${ }^{31}$ Dalam satu kenyataan beliau menyatakan bahawa, "China is weak. The only thing we can depend upon is the hearts of the people. If we lose them, how can we maintain our country? "32 Akibat daripada itu aktiviti Boxer menjadi perang antara kerajaan China dan kuasa asing. Kesannya membawa kepada banyak harta benda orang asing telah musnah termasuk beberapa pejabat kedutaan terbakar kecuali kedutaan British, Perancis dan Jerman di Beijing.

Senario di atas ini cukup mencemaskan orang asing termasuk di Tianjin. Penduduk asing terpaksa berlindung di konsesi asing bagi mengelakkan ancaman daripada Boxer. Konsesi asing Perancis yang berdekatan dengan bandar Tianjin yang dikuasai oleh pihak China menerima kesan paling teruk daripada bedilan pihak Boxer. Walaupun Konsesi British terlepas daripada serangan terus bedilan Boxer tetapi mereka tetap menerima kesan daripada ancaman Boxer. Pihak berkuasa tempatan di Konsesi British sibuk mempertahankan konsesi tersebut dengan sokongan penduduk asing di konsesi tersebut. Namun demikian tanpa sokongan daripada tentera asing konsesi asing di Tianjin ini boleh jatuh ke tangan pihak Boxer.

Oleh itu James Watts telah ditugaskan untuk mencari bantuan pihak kuasa asing di Taku. Beliau bersama-sama tiga orang yang lain telah cuba melepasi kepungan konsesi mereka untuk melaksanakan misi ini mendapat bantuan daripada tentera asing di Taku. ${ }^{33}$ Watts dan rombongannya berjaya menembusi kepungan ini dan menyampaikan berita tentang kegentingan di Tianjin kepada pihak tentera asing. Dengan tibanya tentera asing pada 11 Julai 1900 memberi 
semangat lebih kepada penduduk asing di Tianjin untuk diselamatkan. Tentera asing ini berjaya menawan bandar Tianjin pada 14 Julai $1900 .{ }^{34}$ Dengan itu juga tamatlah kepungan 27 hari Boxer ke atas konsesi-konsesi asing di Tianjin. Tentera asing ini meneruskan ekspedisi ketenteran untuk menundukkan Kebangkitan Boxer dengan mara ke utara dan menawan Beijing pada Ogos 1900. Dengan itu juga tamatnya Kebangkitan Boxer yang diikuti dengan Protokol Boxer pada tahun 7 September 1901. ${ }^{35}$

Manakala kuasa asing yang menyertai tentera berikat mengalahkan Boxer mula menuntut lebih banyak konsesi-konsesi dibuka untuk kuasa-kuasa asing ini. British misalnya telah memperluaskan konsesinya sehingga meliputi kawasan seluas 6149 mou. Manakala Rusia telah mendapat hak membina konsesi pada November 1900 . Kerajaan Itali pula telah diberi konsesi pada Februari 1901. Manakala Belgium pula mendapat konsesi pada tahun 1902. Kuasa Barat terakhir memiliki konsesi di Tianjin ialah Austria-Hungary. Manakala Jerman dan Jepun telah memiliki konsesi sebelum tercetusnya Kebangkitan Boxer. Kedua-dua kuasa ini telah mengambil kesempatan daripada kekalahan China dalam Perang China-Jepun (1894-1895). ${ }^{36}$

Bagi Konsesi British, serangan dan kepungan selama 27 hari ini telah membawa beberapa kerosakan fizikal ke atas bangunan-bangunan di konsesi tersebut. Antara bangunan yang rosak ialah bangunan kepunyaan syarikatsyarikat asing seperti pejabat Taku Tug and Lighter Company; Hongkong and Shanghai Bank, the Chartered Bank, Astor House Hotel. Selain itu Konsulat Besar British and beberapa rumah kediaman juga turun mengalami kerosakan. Manakala gudang Butterfield and Swire dan Mackenzie \& Co., telah dimusnahkan. ${ }^{37}$ Sementara itu, bandar Tianjin pula diletakkan di bawah kawalan tentera asing di bawah pentadbiran Tianjin Provisional Government (TGP). ${ }^{38}$ TGP ini mempunyai beberapa tanggungjawab seperti berikut:-

1. Mengembalikan keamanan dan keselamatan.

2. Mengadakan usaha membersih dan menghapuskan penyakit berjangkit.

3. Memastikan tentera asing terus menerima bekalan makanan yang mencukupi.

4. Melindungi dan merekod harta benda milik kerajaan China dan pihak individu.

5. Mengelak berlakunya kekurangan makanan dalam kalangan penduduk China. ${ }^{39}$

TPG telah menjadi majlis perbandaran yang cuba memulih semula Tianjin yang banyak mengemabli kemusnahan akibat peperangan dengan tentera asing. Pentadbiran TPG ini ditamatkan pada 15 Ogos 1902 dan dikembalikan kepada pemerintah China. ${ }^{40}$ 
Dua insiden yang berlaku di Tianjin ini menunjukkan bahawa penduduk China tidak berpuas hati dengan pihak asing yang dianggap tidak menghormati kedaulatan China. Walaupun sesetengah sarjana Barat menganggap Boxer pada asalnya bukannya satu reaksi ke atas imperialisme asing, namun kebangkitan Boxer masih mencermin satu tindakan benci ke atas tingkah laku orang asing yang mempersendakan kedaulatan negara mereka. Manakala kemunculan konsesi asing di Tianjin menunjukkan bahawa penduduk China masih tidak suka akan usaha penempatan orang asing yang tidak mahu tunduk kepada pemerintah China. Extraterritoriality ${ }^{41}$ atau hak wilayah asing yang dinikmati oleh penduduk asing membolehkan orang asing bersikap angkuh dan memperkecilkan pihak berkuasa China. Oleh itu konsesi asing ini menjadi sasaran orang China untuk membantah pelakuan orang asing yang kebal daripada undang-undang China. Walaupun Boxer berjaya dihapuskan namun semangat nasionalisme Orang China mula tumbuh dan cuba melawan semula kehadiran orang Barat. Konsesi asing menjadi sasaran mereka selepas itu.

Tindakan mengambil Tianjin oleh TPG dan usaha menuntut lebih banyak konsesi asing di Tianjin berterusan bukan meredakan keadaan penduduk China yang tidak suka akan imperialisme Barat. Malahan mereka mula mengorak langkah untuk menuntut semula hak-hak asing ini dikembalikan kepada China. Sikap dan dasar kuasa asing pula tidak membantu meredakan kemarahan orang China. China selepas Kebangkitan Boxer telah hukum.

Manakala konsesi British di Tianjin pula mengetatkan penyertaan orang China dalam pentadbirannya. Tiada lagi orang China dilantik sebagai ahli majlis tempatan bagi British Municipal Extention Council (BMEC) selepas 1900. Manakala Samuel Lavington Hart iaitu seorang mubaligh Kristian cuba membaiki hubungan orang China dan Barat dengan menubuh Tianjin AngloChinese College (TACC) untuk memberi pendidikan kepada anak-anak China ${ }^{42}$ Walaupun langkah ini dianggap sebagai langkah pemulihan namun menggunakan agama bagi memulihkan hubungan dianggap sebagai satu kesilapan. Ini kerana salah satu sebab meletusnya Tianjin Massacre dan Kebangkitan Boxer ialah sebab-sebab agama Kristian. Tahun-tahun 1920an misalnya telah menyaksikan golongan penyebar agama Kristian menjadi sasaran kerana dianggap sebagai agen imperialisme yang cuba mengawal anak-anak China daripada terlibat dalam gerakan nasionalisme.

\section{Pembangunan}

Kebangkitan Boxer tidak menghalang pembangunan konsesi British. Malahan konsesi ini terus berkembang maju. Pada lewat abad ke-19, Konsesi British mempunyai dua majlis bandaran kerana pada tahun 1897 British dapat menyewa sebidang lagi tanah yang diluluskan oleh Pegawai Taotai China. Oleh kerana MPBT tidak mahu menggabungkan tanah baru yang disewa itu maka munculnya BMEC. Pada November 1900, British mendapat sebidang lagi tanah yang mereka kenali sebagai the British Extra-mural Area. Tanah 
yang disewakan ini tidak mempunyai pentadbiran. Manakala konsesi yang dimiliki oleh Amerika Syarikat pula diserahkan kepada pihak British pada tahun 1902. Dengan itu, Konsesi British merupakan konsesi terbesar di Tianjin yang mempunyai saiz 6140 mou. (Lihat peta di halaman 10)

Konsesi-konsesi Kuasa Asing di Tianjin

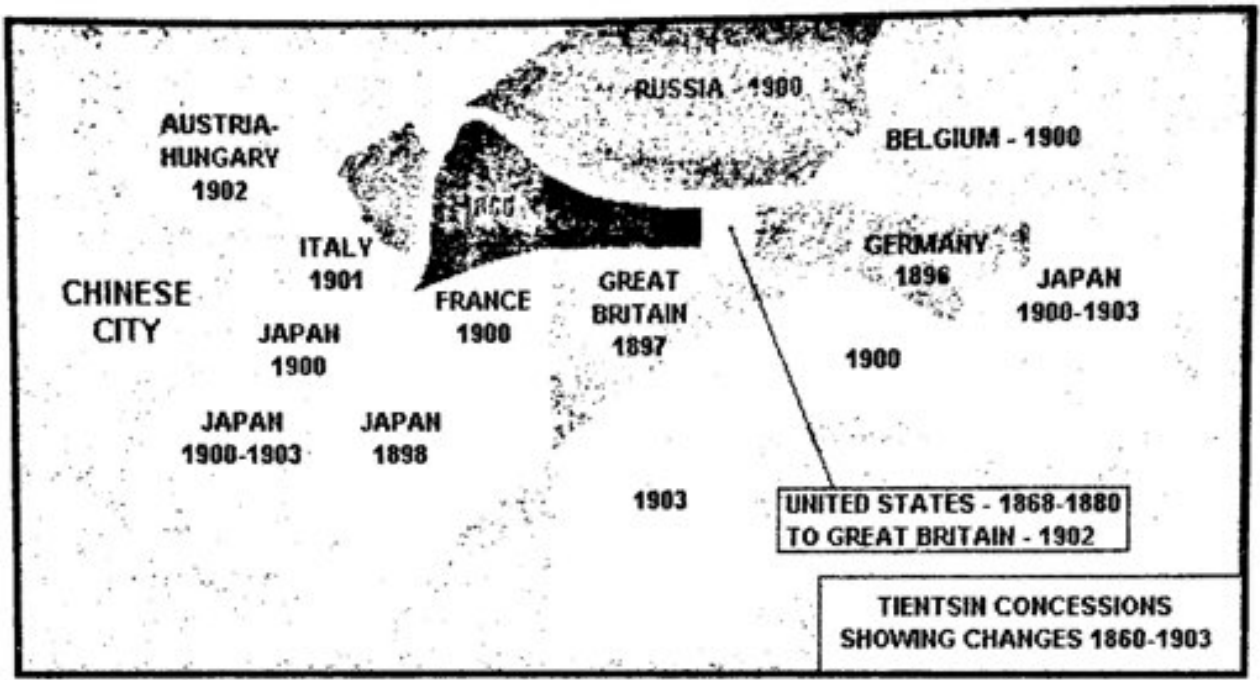

Sumber: 'The Foreign Concessions and Special Administrative Areas,' http:// www.geocities.com/eureka/plaza/7750/tientsin01.html

29 December 2006

Oleh kerana terdapat empat bahagian dalam konsesi British maka terdapat usaha untuk menyatukannya. Namun demikian usaha awal dilakukan pada penghujung abad ke-19 tidak dapat dilaksanakan. Ini kerana Konsul British di Tianjin iaitu B. C. G. Scott tidak menjayakan usaha awal ini. ${ }^{43}$ Pada tahun 1917 usaha penyatuan ini diutarakan lagi. Walau bagaimanapun terdapat tentangan daripada ahli Majlis MPBT. Mereka yang menentang itu tidak mahu kewangan yang diperolehi dari MPBT digunakan untuk membangunkan konsesi-konsesi British yang lain di Tianjin.

Namun demikian, Konsul Jeneral British mempunyai kuasa besar dalam mendesak pergabungan itu. Walaupun MPBT menjadi kuasa mentadbir, tetapi kuasa Konsul Jeneral British lebih besar dalam menentu hala tuju masa depan konsesi British. Menurut Land Regulation bagi MPBT, meletakkan kuasa Konsul General British mempunyai kuasa besar dalam memanggil untuk mesyuarat agung pengundi di Konsesi British, mempunyai hak veto bagi setiap keputusan dan mempengerusi majlis tersebut. ${ }^{44}$ Konsul General Jeneral British ini juga mempunyai kuasa untuk melihat dan meluluskan atau tidak undangundang kecil yang dikeluarkan oleh pihak majlis bandaran. ${ }^{45}$ Oleh itu MPBT tidak mempunyai banyak kuasa dalam menentukan masa depan konsesi ini. MPBT hanya mempunyai kuasa mentadbir, menjaga kebersihan, memelihara 
keselamatan dan mengambil pekerja majlis perbandaran. Atas sebab ini maka tentangan daripada MPBT untuk bergabung tidak begitu berjaya. Oleh itu pada 1919 semua konsesi-konsesi British telah disatukan di bawah MPBT. Manakala bilangan keahlian dalam majlis MPBT ini ditambah dan seorang perwakilan China dilantik.

Selepas pergabungan, pentadbiran MPBT dibesarkan dengan pelbagai jabatan bagi memberi kemudahan kepada penduduk konsesi ini. Pentadbiran MPBT telah dipecahkan kepada dua bahagian iaitu bahagian seketariat dan akaun. Bahagian seketariat berfungsi sebagai pentadbir dan bahagian akaun berfungsi sebagai bahagian kewangan. Manakala terdapat tiga jabatan utama mengurus kemudahan dalam konsesi ini iaitu Jabatan Kerja Raya, Jabatan Elektrik dan Jabatan Bekalan Air. Dalam menjaga keselamatan konsesi ini terdapatnya Polis Bandaran yang diketuai oleh seorang persuruhjaya dan dua orang inspektor. Manakala bilangan anggota polis bertambah dari 229 orang pada tahun 1920 kepada 338 orang dan kira-kira 700 orang pada tahun 1924 dan 1940 masing-masing. ${ }^{46}$

Jumlah Pekerja MPBT disetiap jabatan mengikut bangsa dalam tahun 1934, 1938 dan 1939

\begin{tabular}{|c|c|c|c|c|c|c|c|c|c|c|c|c|}
\hline \multirow[t]{3}{*}{ Jabatan/Pegawai } & \multicolumn{12}{|c|}{ Bilangan Kakitangan } \\
\hline & \multicolumn{3}{|c|}{1926} & \multicolumn{3}{|c|}{1934} & \multicolumn{3}{|c|}{1938} & \multicolumn{3}{|c|}{1939} \\
\hline & B & $\mathrm{C}$ & $\mathbf{T}$ & $\mathrm{B}$ & $\mathrm{C}$ & $\mathrm{T}$ & B & $\mathrm{C}$ & $\mathbf{T}$ & B & $\mathrm{C}$ & $\mathbf{T}$ \\
\hline Seketariat & 3 & 0 & 3 & 3 & 3 & 6 & 3 & 2 & 5 & 3 & 2 & 5 \\
\hline Jabatan Perkaunan & 4 & 0 & 4 & 3 & 5 & 8 & 3 & 6 & 9 & 3 & 6 & 9 \\
\hline Jabatan Kerja Raya & 6 & 0 & 6 & 5 & 4 & 9 & 6 & 5 & 11 & 4 & 8 & 12 \\
\hline Jabatan Elektrik & 3 & 0 & 3 & 2 & 2 & 4 & 2 & 4 & 6 & 3 & 3 & 6 \\
\hline Jabatan Bekalan Air & 2 & 0 & 2 & 1 & 3 & 4 & 2 & 2 & 4 & 2 & 2 & 4 \\
\hline Jabatan Polis & 4 & 0 & 4 & 6 & 6 & 12 & 8 & 9 & 17 & 8 & 9 & 17 \\
\hline Bomba & na & na & na & 2 & 0 & 2 & 2 & 2 & 4 & 2 & 0 & 2 \\
\hline Pegawai Pelabuhan & 1 & 0 & 1 & 0 & 1 & 1 & 0 & 1 & 1 & 0 & 1 & 1 \\
\hline Pegawai Kesihatan & 2 & 0 & 2 & 2 & 0 & 2 & 2 & 0 & 2 & 2 & 0 & 2 \\
\hline Kakitangan Hospital & 6 & 0 & 6 & 6 & 2 & 8 & 7 & 4 & 11 & 7 & 4 & 11 \\
\hline Jumlah & 31 & 0 & 31 & 30 & 26 & 56 & 35 & 35 & 70 & 34 & 35 & 69 \\
\hline
\end{tabular}

Sumber: The Directory and Chronicle China, Japan. Corea, ... 1926, p.603, China Hong List 1934, hlm.702, China Hong List 1939, hlm.717-718 and China Hong List 1939 , hlm.700.

B - Orang British

C - Orang China

T - Jumlah

na - Tidak ada data 
Selain menjaga keselamatan dan keamanan konsesi ini terdapat juga pasukan separa tentera yang dikenali sebagai Concession Volunteer Corp. Pasukan ini wujud semasa Kebangkitan Boxer selain pasukan bomba yang diwujudkan bagi menghalang kebakaran. Pasukan ini telah ditubuhkan pada 6 Disember 1902. Lain-lain kemudahan yang disediakan oleh MPBT ialah dua buah hospital dan sebuah sekolah rendah yang ditubuhkan pada tahun 1905. Pelajar yang belajar disekolah ini boleh meneruskan pengajian mereka di peringkat menengah dan tinggi di luar negeri. Sekolah rendah ini juga dibuka untuk semua penduduk konsesi tanpa mengira latarbelakang bangsa mereka. ${ }^{47}$

Penduduk di konsesi ini juga bebas menubuhkan kelab mereka seperti Kelab Tianjin, Kelab Lumba Kuda Tianjin dan Union Jack Club. Manakala golongan mubaligh pula terdiri daripada pelbagai kumpulan. Antaranya ialah London Missionary Society (LMS) dan the United Methodist Mission. LMS yang berpusat di Konsesi British di Tianjin juga mempunyai pusat operasi dan aktiviti di luar Tianjin iaitu di Tsangchow dan Siaochang. ${ }^{48}$ Golongan pengembang Kristian ini berperanan dalam usaha menyebar agama Kristian mengikut mazhad mereka dan memberi kemudahan kesihatan dan pendidikan kepada penduduk China.

\section{Bangunan Dewan Gordon, Taman Victora (sebelah kiri) dan Hotel Astora}

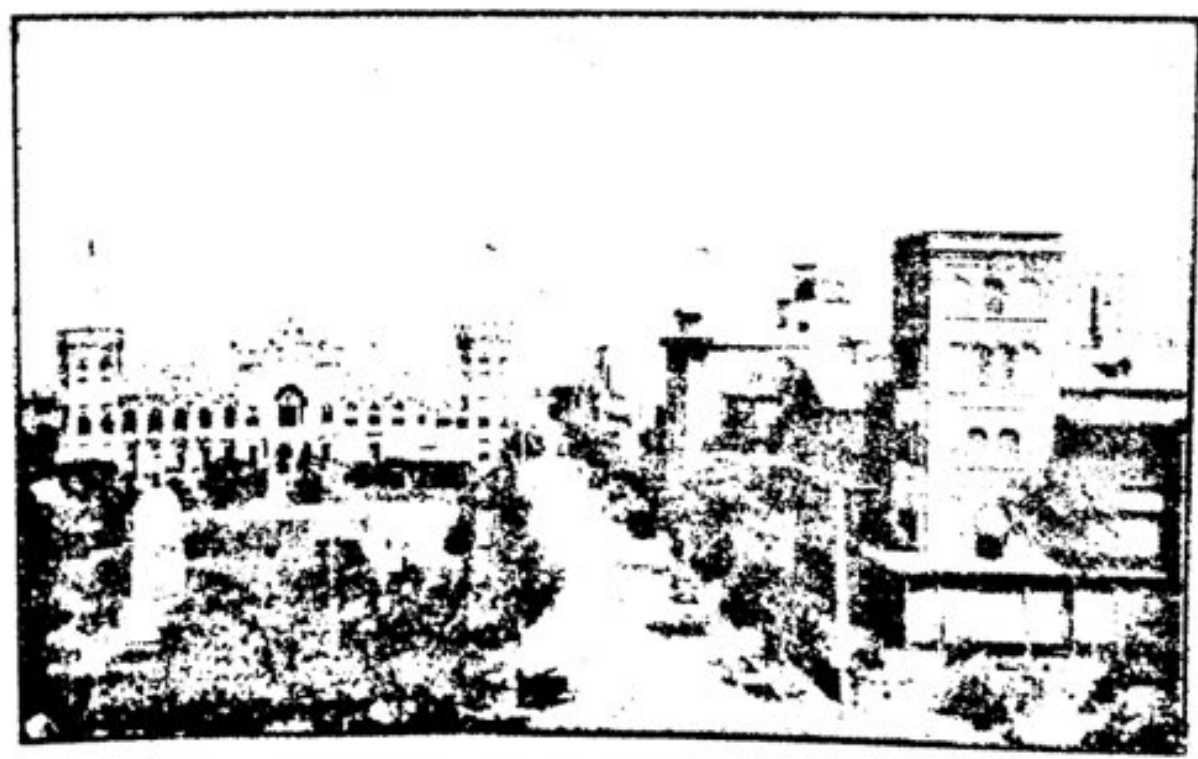

Sumber: Pennell, W. V.. Tientsin North China the Port, Its History, Trade, Industry and Community Life, Tientsin: the Tientsin Press, 1934 


\section{Bangunan KMA di Meadows Road}

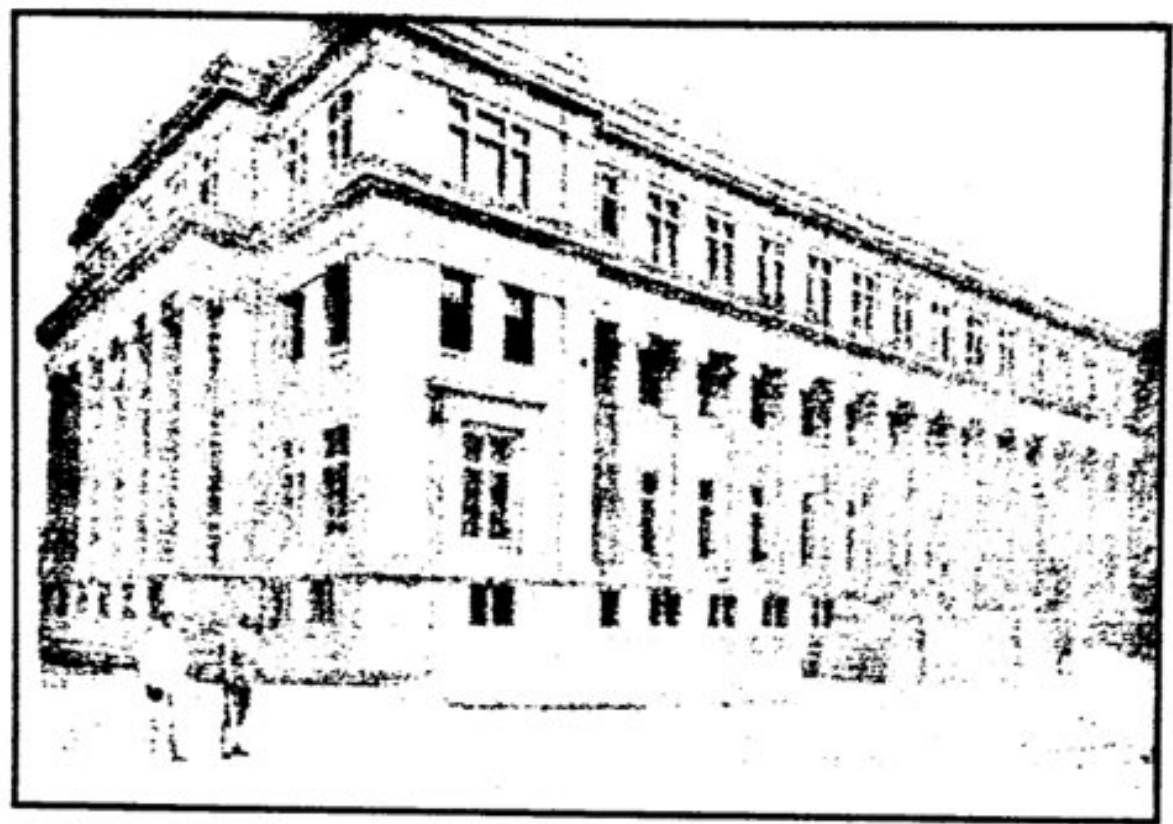

Sumber: Pernell, W. V.. Tientsin North China the Port, Its History, Trade, Industry and Community Life, Tientsin: the Tientsin Press, 1934

\section{Grammar School (Sekolah Rendah)}

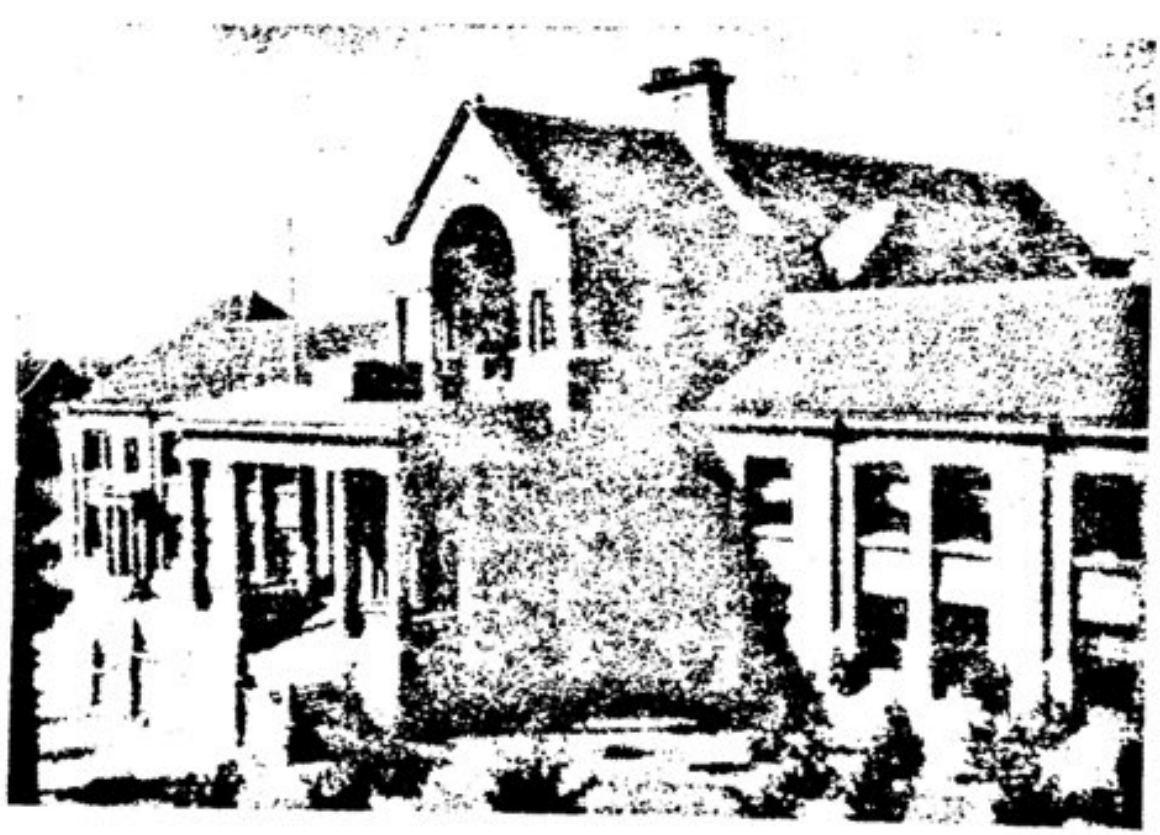

Sumber: Pennell, W. V., Tientsin North China the Port, Its History, Trade, Industry and Community Life, Tientsin: the Tientsin Press, 1934 
Konsesi British pada abad ke-20 telah mencapai pembangunan yang pesat seiringan dengan kepesatan perdagangan. Hasil daripada pembangunan ini telah muncul pelbagai bangunan baru dan besar di Konsesi British. Bangunan Gordon yang dibina sebelum abad ke-20 masih lagi kukuh dan menjadi pusat pentadbiran MPBT. Di bangunan itu juga ditempatkan tempatan berhimpun, tempat mengadakan konsert dan pejabat bagi pegawai MPBT. ${ }^{49}$ Selain itu, terdapat juga beberapa bangunan baru didirikan seperti bangunan Kelab Tianjin (1905), bangunan syarikat-syarikat besar seperti bangunan Kailan Mining Administration (KMA), Hongkong and Shanghai Bank (HSB) dan Empire Theater. ${ }^{50}$

Perkembangan dan pembangunan Konsesi British di Tianjin tidak terganggu oleh Perang Dunia Pertama walaupun ketika itu Konsesi Jerman dan Konsesi Austria-Hungary diambil semula oleh Kerajaan China. ${ }^{51}$ Ini kerana pihak China telah menyertai Pihak Berikat dalam Perang Dunia Pertama untuk melawan Jerman dan Austria-Hungary. Manakala pada tahun 1920 kerajaan China mengambil alih pula Konsesi Rusia kerana pihak kerajaan China tidak mengiktiraf kerajaan Komunis Rusia. Usaha China mengambil semula konsesikonsesi ini menunjukkan bahawa mereka mempunyai keinginan tinggi untuk mengembalikan hak kedaulatan China. Oleh itu selepas Perang Dunia Pertama, tuntutan-tuntutan mendapat hak kedaulatan China ini semakin hebat. Tuntutan ini menyebabkan Kerajaan Belgium akur untuk menyerahkan konsesi mereka pada tahun 1928. ${ }^{52}$ Namun demikian, konsesi British masih bertahan walaupun adanya tuntutan untuk mendapat hak ini. Perasaan takut akan perdagangan mereka terganggu dan diancam oleh pihak China menyebabkan tentangan penduduk British di Tianjin untuk mengambilkan konsesi British kepada pihak berkuasa China. Ini kerana perdagangan firma-firma perniagaan British telah berkembang maju di Tianjin. Perkara ini boleh dibincangkan dalam tajuk
berikutnya.

\section{Penduduk dan Ekonomi}

Sejajar dengan perkembangan pesat Konsesi British ini membawa kepada pertambahan penduduk di konsesi ini (lihat lampiran A). Penduduk di konsesi ini bertambah dengan kadar yang besar antara tahun 1913 sehingga 1938. pada tahun 1938 jumlah penduduknya 1925 kenaiknya ialah 52 peratus. Manakala Pertambahan penduduk di konsesi na adalah berjumlah 76,815 orang. dikecapi oleh konsesi ini. Dengan ka menunjukkan kemakmuran yang pembunuhan beramai-ramai pada tahuta lain gangguan daripada insiden tahun 1900 tidak menyekat kemakmun 1870 dan Kebangkitan Boxer pada telah bertambah. Penduduk paling ram konsesi ini. Malahan jumlah mereka Penduduk China bertambah setiap tahun. di konsesi ini ialah Orang China. daripada keseluruhan penduduk di konsesi in mereka antara 90-95 peratus mereka dalam konsesi ini agak terhad (sehing. Namun demikian, peluang tidak mempunyai suara besar dalam majlis tega 1925)..$^{53}$ Ini kerana mereka 
oleh seorang perwakilan sejak tahun 1919 dan hanya desakan pihak nasionalisme pada tahun 1925 barulah jumlah mereka adalah sama antara perwakilan British dan China. ${ }^{54}$

Walaupun berlakunya diskriminasi terhadap penduduk China, namun pihak MPBT tidak bertindak untuk menyekat mereka tinggal dan berkerja di konsesi ini. Ini kerana jumlah mereka yang ramai itu memang dialu-alukan oleh pihak berkuasa MPBT. Keperluan guna tenaga yang ramai serta murah amat diperlukan bagi membantu pertumbuhan ekonomi di konsesi ini. Jumlah penduduk British yang kecil pula tidak mampu untuk membantu pembangunan konsesi ini tanpa sokongan orang China ini.

Jika dibandingkan antara penduduk China dan British, jumlah penduduk British kecil. Namun penduduk British merupakan penduduk asing terbesar yang mewakili hanya antara 2-3 peratus sahaja. Jumlah penduduk British juga bertambah setiap tahun kecuali pada tahun 1938 (Lihat Lampiran A). Pertambahan penduduk orang British ini juga menunjukkan bahawa berlakunya kemakmuran kepada konsesi tersebut. Keadaan serupa juga berlaku ke atas penduduk asing yang lain. Kebanyakan daripada jumlah mereka telah bertambah dari tahun ke tahun.

Pertambahan penduduk di konsesi ini disebabkan kemajuan dalam bidang perdagang. Lampiran 2 menunjukkan perkembangan perdagangan di Tianjin. Seperti dinyatakan pada awal tadi Tianjin yang berdekatan dengan bahan mentah dari wilayah-wilayah berdekatan dengannya membantu perkembangan perdagangan ini. Manakala Tianjin pula menjadi pintu keluar kepada barangan pedalaman China di utara dan barat. Tianjin juga menjadi pintu masuk kepada barangan luar masuk ke utara China. China yang memerlukan pemodenan telah membawa pelbagai peralatan dan barangan luar untuk tujuan tersebut. Atas sebab itu barangan seperti senjata, besi, barangan makanan (seperti tepung, gula, arak dan teh), mesin tiap, kereta, kertas dan barangan kapas dibawa masuk ke utara China. Dengan adanya kemajuan ini menyebabkan Tianjin bukan sahaja menjadi pelabuhan mengumpul, menyebar dan memunggah barang tetapi juga pusat industri barangan tempatan. Di Tianjin ini munculnya pelbagai kilang barangan harian seperti kilang karpet, kilang memintal benang kapas, kilang mancis dan sabun. ${ }^{\text {ss }}$

Perkembangan perdagangan di Tianjin amnya dan di Konsesi British khasnya dibantu pula oleh perkembangan pengangkutan yang menghubungi kawasan pengeluaran bahan mentah ke bandar Tianjin. Jalan darat misalnya mula diperkembangkan dengan pembinaan jalan keretapi. Pembinaan jalan keretapi ini bagi memudah dan mempercepatkan pergangkutan darat yang dahulunya dikuasai oleh karavan-karavan dagang yang dibantu oleh tenaga binatang. Jalan keretapi pertama dibina ialah Jalan Keretapi Peking Mukden pada tahun $1884 .^{56}$ Jaringan jalan keretapi itu menghubungi Tianjin dengan utara China dan Hankow (di bahagian tengah), dan juga menghubungi kawasan perlombongan arang batu iaitu Tangshan (Tongshan) dan Qinhuangdao (Chiwangtao). Jalan keretapi ini juga menghubungi Tianjin dengan Taku bagi memberi akses kepada Tianjin dengan dunia antarabangsa. 
Pada tahun 1912 dibina pula jalan keretapi Tianjin-Pukow. ${ }^{57}$ Jalan keretapi ini menghungi Tianjin dengan bahagian hilir Lembah Sungai Yangtze. Jalan keretapi ini memudahkan Tianjin dihubungkan dengan Nanking yang mempunyai jalan keretapi Shanghai-Nanjing. ${ }^{58}$ Dengan kata lain jalan keretapi ini mempertemukan Tianjin dengan kawasan ekonomi perdagang tersibuk di China ketika itu iaitu Shanghai. Tianjin juga boleh dihubungi dengan jalan air. Terdapat Terusan Besar yang dibina zaman Dinasti Sui membolehkan Tianjin dihubungi dengan kawasan tengah China. Salah satu masalah Tianjin ialah Sungai Hai selalu mengalami kebekuan apabila musim sejuk melanda utara China. Oleh itu pihak kuasa asing telah menubuhkan Suruhanjaya Pemeliharaan Sungai Hai pada tahun 1901. Suruhanjaya itu mempunyai tugas memastikan keselamatan dan kelancaran perjalanan Sungai Hai daripada sebarang masalah. Ini merupakan kesungguhan pihak kuasa asing yang menganggotai suruhanjaya itu untuk memastikan kemajuan perdagangan di Tianjin tidak terganggu.

Iklim perdagangan yang menggalakkan di Tianjin membawa kepada pertambahan firma-firma perniagaan British menjalankan operasi dagang mereka di Tianjin. Pada tahun 1861 terdpat hanya tiga firma British di Tianjin. Jumlah ini bertambah kepada 19 buah firma British pada tahun $1863 .{ }^{59}$ Jumlah ini bertambah lagi kepada 33,61 dan 71 buah pada tahun $1874^{60}, 1889^{61}$ dan $1895^{62}$ masing-masing. Pada tahun 1917 terdapat 357 buah syarikat asing di Tianjin. Daripada jumlah tersebut, 81 buah adalah milik penduduk British. Setahun selepas itu terdapat 82 buah firma British (tidak termasuk syarikatsyarikat perubatan) di Konsesi British. Manakala 13 buah firma British pula terdapat di terdapat konsesi-konsesi asing yang lain. Tambahan daripada itu kira-kira empat ke lima firma terdapat di luar konsesi-konsesi asing. ${ }^{63}$

Terdapat pelbagai firma-firma British di Tianjin termasuk firma-firma besar seperti the KMA, Jardine Matheson \& Co., Butterfield and Swire dan $\mathrm{HSB}^{64}$ Firma-firma besar ini terlibat dalam perdagangan eksport dan import, dan beroperasi bukan setakat di Tianjin tetapi di kawasan pendalaman China. Manakala firma-firma kecil termasuk Caldbeck Macgregor \& Co. Ltd., Crystal Ltd., E. Pennell \& Co., Edward Evans \& Sons Ltd. dan Hall \& Holtz, Ltd. ${ }^{65}$ Firma-firma kecil ini menjadi syarikat pembekal barangan harian dan makanan, dan memberi khidmat membuat baju atau membersih air. Firma-firma ini hanya beroperasi dalam konsesi ini sahaja.

Selain dari firma-firma perniagaan British, kuasa asing lain juga mempunyai banyak kepentingan di Tianjin. Antara firma-firma perniagaan asing yang mempunyai banyak kepentingan ialah Jepun, Amerika Syarikat, Jerman dan Rusia. Firma-firma perniagaan asing ini menjadi persaing utama kepada firma-firma British. Keadaan ini menambahkan kerancakan dalam perkembangan perdagangan di Tianjin. Sebagai contohnya HSB merupakan bank asing pertama muncul di Tianjin (1881). Penubuhan bank ini diikuti dengan penubuhan beberapa bank asing yang lain seperti Deutsch Asiatische Bank (1890), Russo-Chinese Bank (1897), dan Yokohama Specie Bank 
(1899).$^{66}$ Ini memperlihatkan persaingan antara firma-firma perniagaan asing di Tianjin. Hanya peranan Amerika Syarikat tidak dilihat mencabar dalam menyaingi kehebatan firma-firma British. Keadaan ini boleh dilihat pada tahun 1917 hanya 27 buah firma perniagaan British jika dibandingkan dengan 81 buah firma milik British. ${ }^{67}$

Manakala firma-firma perniagaan Jerman yang mengalami kesukaran selepas Perang Dunia Pertama mula menunjukkan tanda-tanda untuk meluaskan pengaruhnya di Tianjin. Firma-firma Jerman ini telah cuba menanam semula pelaburan mereka dan menggalakkan lagi perdagangan mereka dengan China. Manakala Rusia pula mempunyai potensi untuk mengubahkan haluan dagang dari Tianjin ke Vladivostock. ${ }^{68}$ Kepentingan firma-firma peniagaan Rusia boleh dilihat daripada peningkatan penduduknya di Konsesi British. Jumlah penduduk Rusia telah bertambah dari 43 dalam tahun 1913 kepada 1,527 pada tahun 1929 dan 2,323 pada tahun 1938 . Manakala Jepun boleh dianggap sebagai ancaman besar kepada perdagang British. Kedudukan Jepun di selatan Manchuria memudahkan ancaman kepada kepentingan British. Di Tianjin dan sekitarnya, firma-firma Jepun adalah berjumlah 357 dalam tahun 1917 berbanding dengan 81 firma British. Manakala jumlah penduduk Jepun di Tianjin dan sekitarnya adalah berjumlah 4,752. Jumlah ini adalah separuh penduduk asing di Tianjin dan kawasan sekitarnya pada tahun $1917 .^{69}$

\section{Kesimpulan}

Secara keseluruhannya Konsesi British di Tianjin wujud kerana kepentingan perdagangan British di utara China. Oleh itu tuntutan untuk melancarkan aktiviti-aktiviti perdagangan telah dilakukan. Antaranya adalah tuntutan untuk mendapat hak penempatan. Akhirnya atas dasar tekanan imperialisme Barat ini China terpaksa akur dengan tuntutan Kuasa Barat. Maka wujudnya sebuah konsesi British seperti di Tianjin. Konsesi ini melambangkan pengaruh imperialisme ketara dalam wilayah China. Sesetengah sarjana menganggap konsesi ini sebagai informal empire. Istilah informal empire telah diperkenalkan oleh John Gallagher and Ronald Robinson. Gallagher and Robinson cuba memfokuskan bahawa aktiviti-aktiviti British yang dianggap mengamalkan informal empire adalah menerusi perdagangan, masyarakat, perjanjian dan bantuan kewangan (kadang kala menerusi tentera).

Jikalau kita melihat pula di Konsesi British di Tianjin terdapat kuasa bagi penduduk British menentukan aktiviti harian mereka. Manakala hak wilayah asing yang mereka nikmati pula menghalang pihak berkuasa China campur tangan dalam aktiviti harian konsesi tersebut. Dengan itu segala aktiviti di Konsesi British ditentukan oleh penduduk British. Kesan yang nyata boleh dilihat dari segi rupa bentuk fizikal konsesi ini yang tidak ubah seperti satu kawasan replika bandar-bandar di England. 
Oleh itu bentuk bandar itu mencermin keasingan daripada bandar China yang lain. Manakala jalan-jalannya pula dinamakan dengan nama Inggeris dan pertumbuhanan kelab-kelab sosial barat pula memenuhi tuntutan masyarakat Barat akan perlunya satu ruang berpesatuan seperti yang ada di barat. Manakala sukan-sukan Barat seperti lumba kuda, lumba anjing dan polo diperkenalkan di ('hina untuk memenuhi masa lapang Orang British (dan Barat). Walaupun terdapat kelonggaran dalam penyertaan orang China dalam MPBT tetapi penguasaan Orang British masih kuat. Mereka menentukan polisi bagi konsesi itu. Keadaan ini bertambah penting kepada Orang British dengan berkembangnya perdagangan. Orang British tidak percaya akan Orang China mampu untuk membangunkan perdagangan di Tianjin. Malahan mereka menganggap Orang China membawa masalah jikalau diberi kuasa di konsesi ini. Keadaan ini menimbulkan bukan setakat perasaan curiga malah membawa polisi diskriminasi.

Kebangkitan Boxer membuktikan bahawa orang China marah kepada orang asing yang dianggap memperkecilkan kedaulatan China. Walaupun elemen-clemen imperialism dalam konsesi ini bukan penyebab kepada kebangkitan itu, tetapi perasaan orang Cina juga marah kerana konsesi itu melambangkan penjajahan kuasa asing di China. Oleh itu perasaan tidak suka dijajah berterusan sehingga membawa kepada kebangkitan nasionalisme di China pada akhir abad ke-20 dengan aktiviti revolusi yang digerakkan oleh Dr. Sun Yat Sen. Namun demikian aktiviti harian di Konsesi Britsih di Tianjin tctap berjalan dengan biasa walaupun adanya gerakan mengulingkan monaki di China pada awal tahun 1900. Malahan perdagangan di Tianjin berkembang pesat dan membawa banyak keuntungan kepada peniaga-peniaga British. Hasil kemakmuran itu membawa kepada pembangunan dalam Konsesi British.

Pembangunan ini mencbalkan lagi sikap imperialisme orang British di Tianjin. Malahan penduduk British yang bekerja di Tianjin mula menganggap Tianjin sebagai kawasan kediaman mereka yang kekal dan harus dimiliki oleh penduduk British. Tambahan rupa konsesi ini yang mirip bandar-bandar di England yang secara tidak langsung menanam perasaan orang British bahawa konsesi itu adalah sebahagian bandar milik British. Perasaan menebal untuk mempertahankan hak orang British ini membawa kepada penentangan mereka terhadap tuntutan untuk mengambil semula konsesi ini oleh kerajaan China pada tahun 1927. Tentangan penduduk British ini menyukarkan usaha Kerajaan British mengikis tanggapan imperialisme oleh orang China terhadap orang British. Akhirnya Kerajaan British terpaksa menggunakan kuasa mutlaknya untuk mendesak MPBT untuk mengadakan rundingan bagi memulangkan konsesi ini kepada pihak kerajaan China. 


\section{Lampiran A}

Jumlah Penduduk di Konsesi British, Tianjin

\begin{tabular}{|c|c|c|c|c|c|}
\hline Warganegara & 1913 & 1925 & 1929 & 1934 & 1938 \\
\hline Amerika & 72 & 294 & 273 & 252 & 185 \\
\hline Armenia & - & - & 15 & 3 & 10 \\
\hline Australia & 5 & - & 7 & 10 & 6 \\
\hline Belgium & 12 & 4 & 8 & 24 & 26 \\
\hline Brazil & - & - & - & 5 & 2 \\
\hline British & 388 & 682 & 755 & 1,451 & 1,372 \\
\hline India (British) & 48 & 35 & 25 & 52 & 18 \\
\hline Kanada & - & - & - & 1 & - \\
\hline China & 15,946 & 33,172 & 36,029 & 42,764 & 72,087 \\
\hline Czechoslovakia & - & - & -5 & 4 & 4 \\
\hline Denmark & 4 & 11 & 4 & 10 & 4 \\
\hline Belanda & $=$ & - & 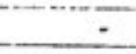 & 5 & 3 \\
\hline Estonia & - & - & $\therefore$ & 9 & 5 \\
\hline Perancis & 15 & 22 & 30 & 55 & 69 \\
\hline Georgia & $\therefore$ & $\therefore$ & - & 6. & -2 \\
\hline Jerman & 141 & 25 & 90 & 85 & 111 \\
\hline Yunani & 21 & - & 11 & 14 & 28 \\
\hline Hungary & - & - & - & 3 & 7 \\
\hline Itali & 11 & 18 & 13 & 29 & 32 \\
\hline Jepun & 84 & 107 & 160 & 89 & 294 \\
\hline Yahudi & - & - & 24 & 232 & $\therefore$ \\
\hline Korea & 3 & 3 & - & -1 & - \\
\hline Latvia & $\therefore$ & 7 & 13 & 20 & 10 \\
\hline Lithuania & $=$ & - & $\overline{4}$ & 16 & 22 \\
\hline Voruay & - & 8 & - & 2 & -1 \\
\hline Parsi & $=$ & - & $\therefore$ & 3 & 6 \\
\hline Peru & $\therefore$ & $\therefore$ & 1 & - & $=$ \\
\hline Filipına & $\therefore$ & 70 & 24 & 15 & 19 \\
\hline Poland & - & 21 & 75 & 48. & 72 \\
\hline Portugis .. & 2. & 2 & 10 & 7 & 21. \\
\hline Romania & $\therefore$ & 1 & 6 & 8 & 3 \\
\hline Russıa & 43 & 731 & 1,527 & 1.448 & 2,323 \\
\hline Serbia & $\because$ & - & - & - & 6 \\
\hline Sepanyol & - & 4 & $\therefore$ & 4 & 4 \\
\hline Sweden & - & - & 3 & 2 & 6 \\
\hline Swiss & 8 & $=$ & 14 & 10 & 22 \\
\hline Tartar & - & $=$ & - & 11 & - \\
\hline Turkey & - & - & 20 & 13 & 12 \\
\hline I'krain & - & - & - & 7 & - \\
\hline Yugoslavia & $\therefore$ & - & - & - & 6 \\
\hline Total & 16.803 & 35,217 & 39,146 & 46,809 & 76,815 \\
\hline
\end{tabular}

Sumber: British Municipal Council, Tientsin, Reports of Council for the year ended December, 31, 1938, and Budget for the year ended December 31, 1939

(Tientsin: Tientsin Press Limited, 1939), hlm.9. 


\section{Lampiran B}

Pembangunan Perdagangan di Tianjin (Tahun-tahun terpilib)

\begin{tabular}{|l|c|c|c|c|}
\hline Tahun & Jumlah (Tahil) & Import(Tahil) & Eksport(Tahil) & Hasil(Tahil) \\
\hline 1861 & $5,475,644$ & $5,014,071$ & 461,573 & \\
\hline 1871 & $18,557,682$ & $17,610,540$ & 947,142 & 441,162 \\
\hline 1881 & $21,606,231$ & $19,105,554$ & $2,500,777$ & 382,540 \\
\hline 1891 & $37,245,515$ & $26,546,064$ & $4,700,451$ & 590,455 \\
\hline 1900 & $31,920,658$ & $23,847,274$ & $8,073,384$ & 516,707 \\
\hline 1901 & $49,411,423$ & $39,257,317$ & $10,154,106$ & 764,514 \\
\hline 1911 & $116,536,648$ & $77,241,699$ & $39,294,949$ & $3,421,543$ \\
\hline 1921 & $224,779,202$ & $161,160,671$ & $63,618,531$ & $6,878,496$ \\
\hline 1924 & $251,695,599$ & $164,128,861$ & $87,566,738$ & $6,922,577$ \\
\hline
\end{tabular}

Sumber: O.D. Rasmussen, Tientsin, hlm.298-299.

\section{NOTA}

1 Kwan Man Bun, The Salt Merchants of Tianjin: State-Making and Civil Society in Late Imperial China, Honolulu: University of Hawai'i Press, 2001, hlm. 13 dan John King Fairbank, China: A New History, Cambridge MA: Harvard University Press, 1994, hlm. 77-78.

2 Edward L. Farmer, Early Ming Government: the Evolution of Dual Capital, Cambridge, M. A.: Harvard East Asia Monographs, 1976, hlm. 156.

3 Kwan Man Bun, The Salt Merchants of Tianjin, hlm. 13 dan 29, dan Peking. North China, South Manchuria and Korea: With Maps, Plans and Illustrations, Firth Edition, London: Thos. Cook \& Son., 1924, hlm. 96.

4 Ruth Rogaski, Hygienic Modernity: Meanings of Health and Disease in TreatyPort China, Berkeley: University of California Press, 2004, hlm. 51.

5 Kwan Man Bun, The Salt Merchants of Tianjin, hlm. 16 dipetik daripada Guanzi (1920), Juan 22, 1a-2b.

6 Britten Dean, "Sino-British Relations, 1860-1864: the Implementation of the Commercial TNAvisions of the Treaty of Tianjin During the Ministership of Frederick Bruce," Phd., thesis, Columbia University, 1969, hlm.7.

7 Lihat Immanuel C. Y. Hsu, The Rise Of Modern China, Third Edition, Oxford: Oxford University Press, 1983, hlm. 161-162.

8 Konvensyen Peking ini adalah usaha menamatkan peperangan antara British dan Perancis disatu pihak dan China dipihak yang lain. Oleh itu pihak yang terlibat dalam perang ini telah bersetuju menandatangani perjanjian dalam konvensyen
ini. 'Special Articles: Tianjin's Foreign Concessions'. Oriental Affairs, 10:4, October,
1938, hlm. 194-196.

10 The Chinese Times, 3 November 1888, hlm. 705. 
" Charles George Gordon dilahirkan di Woolwich, London pada tahun 1833. Beliau terlibat dalam expedisi tentera British menawan Beijing pada tahun 1860. Pada tahun 1862 pula Gordon dilantik sebagai ketua kepada tentera Ever Victorious Army. Beliau dengan tenteranya membantu tentera Kerajaan Ch'ing untuk menghapuskan Pemberontakan Taiping (1850-1864). Beliau terkorban dalam usaha membantu tentera British berundur dari Khartoum, Sudan pada tahun 1885 .

12 Desk Hong List; A General and Business Directory for Shanghai, Northern and River Ports, Japan, January 1875, Shanghai: The North-China Herald Office, 1875, hlm. 111.

13 The Hongkong Directory and Hong List for the Far East for 1889, Eighth Publication, Hongkong: Robert Fraser-Smith, hlm. 321

14 The Hongkong Directory and Hong List for the Far East for 1891, Eleventh Publication, Hongkong: Robert Fraser-Smith, hlm. 354; The Hongkong Directory and Hong List for the Far East for 1892, Tenth Publication, Hongkong: Robert Fraser-Smith, hlm. 401; The Hongkong Directory and Hong List for the Far East for 1893, Twelfth Publication, Hongkong: Robert Fraser-Smith, hlm. 416; and The Hongkong Directory and Hong List for the Far East for 1895, Fourteenth Publication, Hongkong: Robert Fraser-Smith, hlm. 440.

is TNA FO228/3179 Letter Sir Miles Lampson to Sir Austen Chamberlain, Peking, $23^{\text {rd }}$ March 1927.

16 Paul A. Cohen, China and Christianity: The Missionary and the Growth of Chinese Antiforeignism, 1860-1870, Cambridge MA: Harvard University Press, 1963, hlm. 88 dan George Thin, The Tianjin Massacre: The Cause of the Late Disturbances in China and How to Secure Permanent Peace, Edinburgh: William Blackwood and Sons, 1870, hlm. 46-56.

17 O. D. Rasmussen, Tianjin: An Illustrated Outline History, Tianjin: The Tianjin Press, Ltd., 1925, hlm. 46 dan The North China Herald, 7 July 1870, hlm. 4.

${ }_{18}$ Rasmussen, Tianjin. hlm. 46.

19 J. K. Fairbank, 'Pattern Behind The Tianjin Massacre', Harvard Journal of Asiatic Studies, Vol.20, No.3/4, Dec., 1957, hlm. 480.

${ }^{20}$ Lihat Lanxin Xiang, The Origins of the Boxer War, London: Routledge Curzon, 2003, hlm. 37 dan Joseph W. Esherick, The Origins of the Boxer Uprising. Berkeley: University of California, 1987, hlm. 114, 183 and 198-200.

21 The Yi Ho Tuan Movement of 1900, Peking: Foreign Languages Press, 1976, hlm. 16.

22 Joseph W. Esherick, The Origins of the Boxer Uprising, him. 85.

${ }^{23}$ Lanxin Xiang, The Origins of the Boxer War, hlm. 37 dan 38.

24 Edmund S. Wehrle, Britain, China, And The Antimissionary Riot, 1891-1900, Minneapolis: University of Minnesota Press, 1966, hlm. 22.

2s Ibid., hlm. 23.

26 Bai Shouyi (ed.), An Outline History of China, Beijing: Foreign Language Press, 1982, hlm. 483.

27 Peter Fleming, The Siege at Peking, London: Readers Union, Rupert Hart-Davis, 1960, hlm. 47 dan Lanxin Xiang, The Origins of the Boxer War, hlm. 141 dan G. Gipps, The Fighting in North China, hlm. 3-4.

${ }^{28}$ G. Gipps, The Fighting in North China, hlm. 5.

29 Victor Purcell, The Boxer Uprising: A Background Study, hlm. 250.

30 The North China Herald, 4 July 1900, hlm. 11 dan Katharine A. Carl, With the Empress Dowager of China, London: Eveleigh Nash, 1906, hlm. 264 -265.

${ }^{31}$ Joseph W. Esherick, The Origins of the Boxer Uprising, hlm. 303.

32 John King Fairbank, The Great Chinese Revolution: 1800-1985, hlm. 137 dan 138. 
31 Correspondence respecting the Disturbances in China, San Francisco: Chinese Materials Center Inc.. 1975. him. 150.

is O. D. Rasmussen. Tientsin: An Illustrated Outline Historn, hlm. 196-199.

3 Victor Purcell. The Boxer Liprising: A Background Sudy: Cambridge: Cambridge Lniversity Press. 1963. hlm. 260-261.

${ }_{36}$ F. C. Jones, Shanghai And Tientsin, London: Humphrey Milford, 1940, hlm. 130131.

3* O. D. Rasmussen. Tientsin: An Illustrated Outline Historn: hlm. 218-219.

35 Thomas P. Bernstein. "After and Fall: Tianjin under Foreign Occupation. 19001902'. Kertas Kerja tidak diterbitkan, 2001, hlm. 4.

39 Rasmussen, Tientsin, hlm. 221.

40 Ibid.. hlm. 225, 227 dan 229.

${ }^{4}$ Satu hak keistimewaan yang diberikan kepada warga asing yang mana penduduk asing ini tidak tertakluk kepada undang-undang dan hukuman daripada Negara China.

42 A. P. Cullen, Lavington Hart of Tientsin, London: The Livingstone Press, 1947, hlm. 15. 20-21 dan 25-26.

43 TNA FO 674 198 Letter from Consul General H. E. Fulford to Chair. of MPBT, Tientsin, C. R. Morling, Tientsin, February 2, 1916.

${ }_{44}$ Land Regulation for the British Municipal Area of Tientsin. Tientsin, 1919. hlm. 2.

${ }^{45}$ Ibid.. hlm. 8.

4 O. D. Rasmussen. The Growth of Tientsin, Tientsin: Tientsin Press Ltd., 1924. hlm. 15 dan 17.

47 SOAS, the SCRR, John Emmett Woodall Papers, 1919-1990. The Story of the Tientsin School.

48 The Christian Occupation of China: A General Survey of the Numerical Strength and Geographical Distribution of the Christian Forces in China made br the Special Committee Survey and Occupation. China Continuation Committee. 1918-1921, Shanghai: China Continuation Committee, 1922, hlm. 59.

49 Brian Power, The Ford of Heaven. New York: Michael Kesend Publishing, Ltd., 1984, hlm. 21.

so 'List of 160 Significant Historic Buildings in Tianjin-1', http://www. The Gordon Hall wayabroad.com/tianjin/text/text45.htmNO, 26 December 2006.

st Xu Guoqi, China and the Great War: China's pursuit of a new Nationalidentity and Internationalization, Cambridge: Cambridge University Press, 2005, hlm. 169 and Rasmussen, The Growth of Tientsin, hlm. 42 and 48. 52 TNA FO228/4015 Agreement between Belgian and China for the retention of
Belgian Concession in Tienstin.

53 Rujukan diambil daripada analisis Lampiran A.

54 Hanya pada akhir tahun 1920an jumlah perwakilan dalam MPBT adalah lima orang untuk orang British dan lima pula Orang China. Rujuk TNA FO228/3838 Minutes of the Annual of the British Municipal Area held in the Gordon Hall on Wednesday
11 April 1928, at 3.30 p.m.

s5 SOAS, the PP MS 2 Confidential Letters, Etc. of Sir Frederick Maze Vol. 1, 19001928. Lihat juga Macmillan, Seaports of the Far East, hlm. 118.

s6 E-Tun Zen Sun, 'The Pattern of Railway Development in Chin. 118. Quarterly. Vol. 14, No. 2. Feb., 1955, hlm. 180. Introduction 1 Oxfond University Press with an introduction by H.J. Lethbridge Introduction Oxford University Press First Issued, with permission and with the University Press, 1984, hlm. 22. 
58 Louis Beale and G. Clinton Pelham, Trade and Economic Conditions in China 1931-33 report, London: His Majesty's Stationery Office, 1933, hlm. 18 dan 19, dan F.C. Jones, Shanghai and Tientsin, hlm. 135.

59 Rasmussen, Tientsin, hlm. 39 and The China Directory for 1863, hlm. 52.

60 The China Directory for 1874, fourth annual publication, New Series, Taipei: reprinted by Ch'eng Wen Publishing Company, 1971, hlm. 1.

of The Hongkong Directory and Hong List for the Far East for 1889, hlm. 320-323.

62 The Hongkong Directory and Hong List for the Far East for 1895, hlm. 439-442.

63 TNA FO228/3836 Enclosure No.1 in Consul-General Sir J.W. Jamieson's dispatch No.5 of January $20^{\text {th }}, 1928$.

64 Lihat "The Hongkong Directory and Honglist for the Far East" for the year 1926, Sixty-fourth year of publication, Hong Kong: The Hongkong Daily Press, Ltd., MDCCCCXXVI.

65 Ibid.

${ }^{6}$ Lord Charles Beresford, The Break-Up of China: With an Account of Its Present Commerce Currency, Waterways Armies, Railways, Politics and Future TNAspects, New York: Harper \& Brothers Publishers, 1899, hlm. 16 and Twentieth Century Impressions of HongKong, Shanghai, and other Treaty Ports of China, hlm. 734.

67 Julean Arnold, Commercial Handbook of China, hlm. 322.

68 TNA FO228/3179 Report of the China Association, Tientsin Branch, and the Tientsin British Chamber of Commerce, 7 February, 1927.

(9) Julean Arnold, Commercial Handbook of China, hlm. 322. 